\title{
Kekuatan Keterangan Saksi Sebagai Alat Bukti Pada Perkara Kekerasan Dalam Rumah Tangga
}

\author{
Oleh : Elias Zadrack Leasa
}

Email : eliaszleasa72@gmail.com

\begin{abstract}
A witness is someone who hears, sees and experiences on something that happens. This witness has an important role in disclosing a problem that occurs including legal issues. The description of this witness is very useful for the sake of investigation, prosecution and justice on a matter heard by the witness himself, witness to see himself and his own natural witness. The information of a witness alone is not sufficient to prove a criminal incident in accordance with the principle of Unus Testis Nulus Testis (Article 185 paragraph (2) KUHAP), then the statements of witnesses having blood relation under Article 168 Criminal Procedure Code can not be accepted as valid evidence. Witnesses in domestic violence are very difficult because the cases that occur within the household are very small and the witness has a blood relation, but in abolition of domestic violance act in Article 55 provides an opportunity if only one witness is provided with another legal evidence, concerning the witness who incest abolition of domestic violence act is a lex specialist from KUHAP.
\end{abstract}

Keysword: power, testimony of witness, violence

\section{A. Pendahuluan}

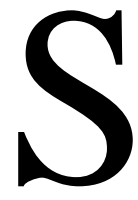
aksi merupakan seseorang yang mendengar, melihat dan mengalami sendiri tentang sesuatu hal yang terjadi. Saksi ini memegang peranan yang penting dalam mengungkapkan suatu permasalahan yang terjadi termasuk permasalahan hukum. Dalam Undang-undang Nomor 8 Tahun 1981 tentang Kitab Undang-undang Hukum Acara Pidana (selanjutnya disingkat KUHAP), pada pada Pasal 1 angka 26 menyebutkan :

Saksi adalah orang yang dapat memberikan keterangan guna kepentingan penyidikan, penuntutan dan peradilan tentang suatu perkara pidana yang ia dengar sendiri, ia lihat sendiri dan ia alami sendiri. 
Keterangan dari seorang saksi ini sangatlah berguna untuk kepentingan penyidikan, penuntutan dan peradilan tentang suatu perkara yang saksi dengar sendiri, saksi lihat sendiri dan saksi alami sendiri. keterangan saksi menurut KUHAP pasal 1 angka 27 menyebutkan :

Keterangan saksi adalah salah satu alat bukti dalam perkara pidana yang berupa keterangan dari saksi mengenai suatu peristiwa pidana yang ia dengar sendiri, ia lihat sendiri dan ia alami sendiri dengan menyebut alasan dari pengetahuannya itu.

Prosesnya dimulai dari tahap penyelidikan dari pihak kepolisian dalam hal ini aparat penegak hukum biasanya jarang sekali dapat secara langsung menangkap tangan pelaku tindak pidana, akan tetapi saksi yang melaporkan, memberikan keterangan dalam penyidikan, kemudian penuntutan sampai dengan putusan oleh majelis hakim. Salah satu alat bukti yang sah dalam proses peradilan pidana adalah keterangan saksi, baik yang mendengar, melihat atau bahkan mengalami sendiri dalam terjadinya suatu tindak pidana yang dilakukan oleh pelaku tindak pidana. ${ }^{1}$

Hal ini beralasan karena saksi merupakan kunci dalam pengungkapan kasus/kejahatan yang terjadi. Namun seorang saksi saja tidak cukup untuk membuktikan kesalahan seseorang, pada Pasal 185 ayat (2) menyebutkan "Keterangan seorang saksi saja tidak cukup untuk membuktikan bahwa terdakwa bersalah terhadap perbuatan yang didakwakan kepadanya”. Kemudian menurut Pasal 168 KUHAP, bahwa yang tidak dapat didengar keterangannya dan dapat mengundurkan diri sebagai saksi adalah :

a) Keluarga sedarah atau semenda dalam garis lurus keatas atau ke bawah sampai derajat ketiga terdakwa atau yang bersama-sama sebagai terdakwa;

${ }^{1}$ Ubwarin. E. (2014), Penegakan Hukum Yang Dilakukan Oleh Polair Polda Maluku, Jurnal Muara Ilmu Sosial, Humaniora, dan Seni, 2 (1), hal 44-51 
b) Saudara dari terdakwa atau yang bersama-sama sebagai terdakwa, saudara ibu atau saudara bapak, juga mereka yang mempunyai hubungan karena perkawinan dan anak-anak saudara terdakwa sampai derajat ketiga;

c) Suami atau istri terdakwa, meskipun sudah bercerai atau yang bersamasama sebagai terdakwa.

Sistem pembuktian KUHAP menganut sistem pembuktian menurut undangundang yang negatif. Menurut Sutarto dalam bukunya mengatakan bahwa "Sistem pembuktian menurut undang-undang yang negatif telah menentukan alat-alat bukti secara limitatif dalam undang-undang dan bagaimana cara mempergunakannya hakim juga terikat pada ketentuan undang-undang"2.

Pembuktian diranah pidana, bukanlah untuk mencari kesalahan pelaku tetapi untuk mencari kebenaran dan keadilan Materiil. Andi Hamzah mengatakan:

Mencari kebenaran materiil itu tidaklah mudah. Hakim yang memeriksa suatu perkara yang menuju kearah ditemukannya kebenaran materiil, berdasar mana ia akan menjatuhkan putusan ,biasanya menemui kesulitan karena betapa tidak,kebenaran materiil yang dicari itu telah lewat beberapa waktu,kadangkadang peristiwanya terjadi beberapa bulan lampau, kadang-kadang berselang beberapa tahun ${ }^{3}$.

Terkait satu saksi bukan saksi, maka dalam setiap perkara pidana harus lebih dari seoranng saksi dan keterangan saksi yang sedarah dalam garis lurus ke atas atau ke bawah hal ini sesuai dengan KUHAP namun Dalam Undang-undang Nomor 23 Tahun 2004 tentang Penghapusan Kekerasan Dalam Rumah Tangga (selanjutnya disingkat UUPKDRT) yang hanya melibatkan suami istri dan anak terkadang yang mejadi saksi yakni istri saja atau bisa juga anak saja tanpa melibatkan orang di luar rumah tangga tersebut. Hal ini tentunya akan bertentangan dengan asas unus testis, nulus testis yakni satu saksi bukan saksi serta akan membawah implikasi hukum

\footnotetext{
${ }^{2}$ Sutarto Suryono, 2018, Hukum Acara pidana jilid II. Badan Penerbit Universitas Diponegoro, Semarang, , hal. 53

${ }^{3}$ Andi Hamzah, 2019, Hukum Acara Pidana Indonesia, Sinar Grafika, Jakarta, hal. 228
} 
mengenai kekuatan keterangan saksi sebagai alat bukti dalam perkara kekerasan dalam rumah tangga.

\section{B. Pembahasan}

\section{Alat Bukti Keterangan Saksi menurut KUHAP}

Proses "pembuktian" hakikatnya memang lebih dominan pada sidang pengadilan guna menemukan kebenaran materiil akan peristiwa yang terjadi dan memberi keyakinan kepada hakim tentang kejadian tersebut sehingga hakim dapat memberikan putusan seadil mungkin. Pada proses pembuktian ini maka adanya korelasi dan interaksi mengenai yang akan diterapkan hakim dalam menemukan kebenaran materiil melalui tahap pembuktian, alat-alat bukti, dan proses pembuktian terhadap aspek-aspek sebagai berikut ${ }^{4}$ :

1. Perbuatan-perbuatan manakah yang dapat dianggap terbukti.

2. Apakah telah terbukti bahwa terdakwa bersalah atas perbuatan-perbuatan yang didakwakan kepadanya.

3. Delik apakah yang dilakukan sehubungan dengan perbuatan-perbuatan itu.

4. Pidana apakah yang harus dijatuhkan kepada terdakwa.

Pembuktian pada hakikatnya selain berorientasi pada pengadilan juga dapat berguna dan penting, baik bagi kehidupan sehari-hari maupun kepentingan lembaga penelitian di mana kekhususan peranan pembuktian untuk pengadilan mempunyai ciri-ciri sebagai berikut ${ }^{5}$ :

${ }^{4}$ Martiman Prodjohamidjojo, 2018, Penerapan Pembuktian Terbalik Dalam Delik Korupsi, Mandar Maju, Bandung, hal. 99

${ }_{5}^{5}$ Bambang Poernomo, 2018, Pokok-pokok Hukum Acara Pidana, Liberty, Yogyakarta, hal. 39 
1. Berkaitan dengan kenyataan mempunyai arti dibidang hukum pidana, antara lain, apakah kelakuan dan hal ihwal yang terjadi itu memenuhi kualifikasi perbuatan pidana atau tidak.

2. Berkaitan dengan kenyataan yang dapat menjadi perkara pidana antara lain, apakah korban yang dibahayakan dan apakah keadaan itu diperbuat oleh manusia atau bukan alam.

3. Diselenggarakan melalui peraturan hukum acara pidana antara lain, ditentukan yang berwenang memeriksa fakta harus dilakukan oleh polisi, jaksa, hakim, dan petugas lain menurut tata cara yang diatur dalam undang-undang.

Pembuktian tentunya tidak terlepas dari sistem pembuktian itu sendiri. Sistem pembuktian adalah merupakan ketentuan tentang bagaimana cara dalam membuktikan dan sandaran dalam menarik kesimpulan tentang terbuktinya apa yang dibuktikan. Pengertian sistem pembuktian yang mengandung isi yang demikian, dapat pula disebut dengan teori atau ajaran pembuktian. Ada beberapa sistem pembuktian yang telah dikenal dalam doktrin hukum acara pidana, ialah ${ }^{6}$ :

1. Sistem keyakinan belaka.

2. Sistem keyakinan dengan alasan logis.

3. Sistem melulu berdasarkan undang-undang.

4. Sistem menurut undang-undang secara terbatas.

Menurut Pasal 184 KUHAP alat bukti dalam perkara pidana bisa berupa keterangan saksi, keterangan ahli, surat, petunjuk dan keterangan terdakwa. Hal-hal yang sudah diketahui umum, tidak perlu dibuktikan lagi. Pada prinsipnya, penggunaan alat bukti saksi dan surat dalam hukum acara pidana tidak berbeda dengan hukum acara perdata baik dalam bentuk maupun kekuatannya. Menurut R. Atang Ranomiharjo, alat-alat bukti yang sah, adalah alat-alat yang ada hubungannya hal.24-25

${ }^{6}$ Adami Chazawi, 2019, Hukum Pembuktian Tindak Pidana Korupsi, Almuni, Bandung, 
dengan suatu tindak pidana, di mana alat-alat tersebut dapat dipergunakan sebagai bahan pembuktian, guna menimbulkan keyakinan bagi hakim, atas kebenaran adanya suatu tindak pidana yang telah dilakukan oleh terdakwa. ${ }^{6}$

Adapun alat-alat bukti yang sah menurut Pasal 184 ayat (1) KUHAP, adalah sebagai berikut:

1. keterangan saksi;

2. keterangan ahli;

3. surat;

4. petunjuk; dan

5. keterangan terdakwa.

Proses pembuktian hakikatnya memang lebih dominan pada sidang pengadilan guna menemukan kebenaran materiil akan peristiwa yang terjadi dan memberi keyakinan kepada hakim tentang kejadian tersebut sehingga hakim dapat memberikan putusan seadil mungkin.

Keterangan saksi sebagai alat bukti ialah apa yang saksi nyatakan di sidang pengadilan (Pasal 155 ayat (1) KUHAP), keterangan ahli sebagai alat bukti ialah apa yang seorang ahli nayatakan di sidang pengadilan (Pasal 186 KUHAP), surat sebagai alat bukti terdapat pada Pasal 187 yang menyatakan bahwa surat dibuat atas sumpah jabatan atau dikuatkan dengan sumpah, adalah :

a. berita acara dan surat lain dalam bentuk resmi yang dibuat oleh pejabat umum yang berwenang atau yang dibuat di hadapannya, yang memuat keterangan tentang kejadian atau keadaan yang didengar, dilihat atau yang dialaminya sendiri, disertai dengan alasan yang jelas dan tegas tentang keterangannya itu

b. surat yang dibuat menurut ketentuan peraturan perundang-undangan atau surat yang dibuat oleh pejabat mengenai hal yang termasuk dalam tata

${ }^{6}$ R. Atang Ranomiharjo dalam Darwan Prinst, 2018, Hukum Acara Pidana Dalam Praktik, Edisi Revisi, Djambatan, Jakarta, hal. 138 
laksana yang menjadi tanggung jawabnya dan yang diperuntukkan bagi pembuktian sesuatu hal atau sesuatu keadaan;

c. surat keterangan dari seorang ahli yang memuat pendapat berdasarkan keahliannya mengenai sesuatu hal atau sesuatu keadaan yang diminta secara resm i dari padanya;

d. surat lain yang hanya dapat berlaku jika ada hubungannya dengan isi dari alat pembuktian yang lain.

Petunjuk sebagai alat bukti ialah perbuatan, kejadian atau keadaan, yang karena persesuaiannya, baik antara yang satu dengan yang lain, maupun dengan tindak pidana itu sendiri, menandakan bahwa telah terjadi suatu tindak pidana dan siapa pelakunya (Pasal 188 ayat (1) KUHAP), petunjuk di dapat dari keterangan saksi, surat dan keterangan terdakwa (Pasal 188 ayat (2) KUHAP). yang terakhir adalah keterangan terdakwa ialah apa yang terdakwa nyatakan di sidang tentang perbuatan yang ia lakukan atau yang ia ketahui sendiri atau alami sendiri (Pasal 189 ayat (1) KUHAP).

Keterangan saksi adalah salah satu bukti dalam perkara pidana yang berupa keterangan dari saksi mengenai suatu peristiwa pidana yang ia (saksi) dengar sendiri, ia lihat sendir dan ia alami sendiri, dengan menyebut alasan dari pengetahuannya itu. (Pasal 1 butir 27 KUHAP).

Dalam keterangan saksi tidak termasuk keterangan yang diperoleh dari orang lain atau Testimonium de Auditu. (Penjelasan Pasal 185 KUHAP). Syarat Keterangan Saksi supaya dapat dipakai sebagai alat bukti yang sah harus memenuhi dua syarat, yaitu:

1) Syarat Formil yaitu bahwa keterangan saksi hanya dapat dianggap sah, apabila diberikan dibawah sumpah. Keterangan saksi yang tidak di bawah sumpah hanya boleh dipergunakan sebagai penambah penyaksian yang sah. 
2) Syarat Materiel yaitu bahwa keterangan seorang saksi saja tidak dapat dianggap sah sebagai alat pembuktian (Unus Testis Nulus Testis). ${ }^{7}$ Akan tetapi keterangan seorang saksi, adalah cukup untuk alat pembuktian salah satu unsur kejahatan yang dituduhkan.

Pengaturan lebih lanjut dari keterangan saksi sebagai pembuktian dapat dilihat seperti apa yang tercantum dalam Pasal 185 KUHAP adalah sebagai berikut:

1) Keterangan saksi sebagai alat bukti; ia;ah apa yang saksi nyatakan di sidang pengadilan;

2) Keterangan seorang saksi saja tidak cukup untuk membuktikan bahwa terdakwa bersalah terhadap perbuatan yang didakwakan kepadanya;

3) Keterangan sebagaimana dimaksud dalam ayat (2) tidak berlaku apabila disertai dengan suatu alat bukti yang sah lainnya;

4) Keterangan beberapa saksi yang berdiri sendiri-sendiri tentang suatu kejadian atau keadaan dapat dipergunakan sebagai suatu alat bukti yang sah apabila keterangan saksi itu ada hubungannya satu dengan yang lain sedemikian rupa, sehingga dapat membenarkan adanya suatu kejadian atau keadaan tertentu;

5) Baik pendapat maupun rekaan yang diperoleh dari hasil pikiran saja, bukan merupakan keterangan saksi;

6) Dalam menilai kebenaran keterangan saksi, hakim harus dengan sungguhsungguh memperhatikan:

- Persesuaian antara keterangan saksi satu dengan yang lain;

- Persesuaian antara keterangan saksi dengan alat bukti lain;

- Alasan yang mungkin dipergunakan oleh saksi untuk memberikan keterangan yang tertentu;

${ }^{7}$ Darwan Prinst, 2019, Hukum Acara Pidana Dalam Praktik, Edisi Revisi, Djambatan, Jakarta, hal. 139 
- Cara hidup dan kesusilaan saksi atau segala sesuatu yang pada umumnya dapat mempengaruhi dapat tidaknya keterangan itu dipercaya.

7) Keterangan dari saksi yang tidak disumpah meskipun sesuai dengan yang lain, tidak merupakan alat bukti, namun apabila keterangan itu sesuai dengan keterangan saksi yang disumpah dapat dipergunakan sebagai tambahan alat bukti yang sah lainnya.

Dalam memeriksa saksi, Hakim, Penuntut Umum, Penasihat Hukum atau Terdakwa tidak boleh mengajukan pertanyaan yang menjerat atau yang bersifat mengarahkan saksi untuk memberikan jawaban tertentu. Pada prinsipnya saksi harus memberikan keterangan secara bebas di muka Hakim. (Pasal 166 KUHAP).

Menjadi saksi dalam perkara pidana adalah menjadi kewajiban dari setiap orang. Oleh karena itu orang yang menolak memberikan keterangannya sebagai saksi dalam suatu perkara pidana dapat dihadapkan ke sidng pengadilan. Pasal 159 ayat (2) KUHAP, menyatakan, bahwa dalam hal saksi tidak hadir, meskipun telah dipanggil dengan sah dan Hakim ketua Sidang mempunyai cukup alas an untuk menyangka bahwa saksi itu tidak akan mau hadir, maka Hakim Ketua Sidang dapat memetintahkan supaya saksi tersebut dihadapkan ke persidangan.

1) Hal mengundurkan diri sebagai saksi

Menurut Pasal 168 KUHAP, bahwa yang tidak dapat didengar keterangannya dan dapat mengundurkan diri sebagai saksi adalah:

a) Keluarga sedarah atau semenda dalam garis lurus ke atas atau ke bawah sampai derajat ketiga terdakwa atau yang bersama-sama sebagai terdakwa;

b) Saudara dari terdakwa atau yang bersama-sama sebagai terdakwa, saudara ibu atau saudara bapak, juga mereka yang mempunyai hubungan karena perkawinan dan anak-anak saudara terdakwa sampai derajat ketiga;

c) Suami atau istri terdakwa, meskipun sudah bercerai atau yang bersamasama sebagai terdakwa. 
Menurut Pasal 169 KUHAP, bahwa mereka sebagaimana dimaksud dalam Pasal 168 KUHAP, apabila menghendakinya dan penuntut umum serta terdakwa secara tegas menyetujuinya dapat memberikan keterangan tanpa disumpah. Sedangkan menurut Pasal 170 KUHAP, yang dapat mengundurkan diri sebagai saksi, adalah mereka yang karena pekerjaan, harkat martabat atau jabatannya diwajibkan menyimpan rahasia dapat minta dibebaskan dari kewajiban untuk memberikan keterangan sebagai saksi, yaitu tentang hal yang dipercayakan kepada mereka. Hakim menentukan sah atau tidaknya segala alasan untuk permintaan tersebut. Orang-orang yang boleh diperiksa untuk memberikan keterangan tanpa disumpah menurut Pasal 171 KUHAP, adalah anak yang umurnya belum cukup lima belas (15) tahun dan belum pernah kawin, serta orang yang sakit ingatan atau sakit jiwa meskipun kadang-kadang ingatannya baik kembali.

2) Jenis-jenis Saksi

Saksi menurut sifatnya dapat dibagi atas:

a) Saksi a charge (memberatkan Terdakwa): Saksi A Charge, adalah saksi dalam perkara pidana yang dipilih dan diajukan oleh penuntut umum, dikarenakan kesaksiannya yang memberatkan terdakwa. Dalam hal saksi yang memberatkan terdakwa yang tercantum dalam surat pelimpahan perkara atau yang diminta oleh terdakwa atau penasihat hukum atau penuntut umum, selama berlangsungnya sidang atau belum dijatuhkannya putusan, hakim ketua sidang wajib mendengar keterangan saksi tersebut. (Pasal 160 (1)c KUHAP).

b) Saksi a de charge (menguntungkan Terdakwa): Saksi A de charge, adalah saksi yang dipilih atau diajukan oleh Penuntut Umum atau terdakwa atau Penasihat hukum, yang sifatnya meringankan terdakwa.

Menurut Pasal 160 ayat (1) c KUHAP, bahwa Hakim ketua sidang wajib mendengar saksi yang demikian, baik yang tercantum dalam surat 
pelimpahan perkara dan atau yang diminta oleh terdakwa atau penasihat Hukum atau Penuntut Umum, selama berlangsungnya sidang atau sebelum dijatuhkannya putusan.

Saksi a de charge yang tercantum dalam surat pelimpahan perkara pemanggilannya dilakukan oleh penuntut umum. Akan tetapi saksi a de charge yang dimintakan oleh terdakwa atau penasihat hukum, pemanggilannya dilakukan oleh terdakwa atau penasihat hukum itu sendiri. Karena penuntut umum dan terdakwa atau penasihat hukum dapat saling menghadapkan saksi. Hal ini sering membawa kesulitan, dalam hal saksi a de charge tersebut sedang berada dalam tahanan yang berwajib. Atau apabila saksi a de charge tersebut telah dipanggil atau diundang oleh terdakwa atau penasihat hukum dua kali berturut-turut secara patut, tetapi tidak mengindahkannya. Apakah ada saksi hukum yang dapat dikenakan terhadap saksi tersebut? Padahal menjadi saksi dalam perkara pidana adalah menjadi kewajiban dari setiap orang, yang artinya apabila saksi itu tidak mau hadir di muka pengadilan, maka ia dapat dihadapkan ke persidangan secara paksa. (Pasal 159 ayat (2) KUHAP). ${ }^{7}$

\section{Kekuatan Keterangan Saksi Dalam Perkara KDRT}

Dalam proses pengungkapan suatu kasus pidana mulai dari tahap penyelidikan sampai pembuktian di persidangan, keberadaan dan peran saksi sangatlah penting. Bahkan menjadi faktor penentu dan keberhasilan dalam pengungkapan suatu perkara pidana.Saksi sebagaimana telah dikemukakan diawal bahwa saksi adalahorang yang dapat memberikan keterangan guna kepentingan penyidikan, penuntutan danperadilan tentang suatu perkara pidana yang ia dengar sendiri, ia lihat sendiri dan ia alami sendiri (Pasal 1 angka 26 KUHAP)

Keberhasilan suatu proses peradilan pidana sangat tergantung pada alat bukti yang berhasil diungkap atau ditemukanterutama yang berkenaan dengan saksi,

${ }^{7}$ Ubwarin. E. (2015), Kebijakan Formulasi Hukum Pidana Dalam Melanggulagi Kejahatan Skimming ATM, Jurnal Sasi, 21 (2), hal 17-20 
banyak kasus yang tidak terungkap akhibat tidak adanya saksi yang dapat mendukung tugas penegak hukum. Selanjutnya Pasal 1 butir 27 KUHAP mengatur sebagai berikut: "keterangan saksi adalah salah satu alat bukti dalam perkara pidana yang berupa keterangan dari saksi mengenai suatu peristiwa pidana yang ia dengar sendiri, ia lihat sendiri dan ia alami sendiri dengan menyebut alasan pengetahuannya itu".

Hal tersebut beralasan karena saksi dalam memberikan keterangan hanya boleh mengenai keadaan yang didengar, dilihat atau dialami oleh saksi itu sendiri, dan tiap-tiap persaksian harus disertai penyebutan hal-hal yang menyebabkan seorang saksi mengetahui hal-hal sesuatu. Bahwa suatu pendapat atau suatu persangkaan yang disusun secara memikirkan dan menyimpulkan hal sesuatu tidak dianggap sebagai keterangan saksi. ${ }^{8}$

Keterangan saksi tidak termasuk keterangan yang diperoleh dari orang lain atau Testimonium de auditu, maksudnya agar hakim lebih cermat dan memperhatikan keterangan yang diberikan saksi harus benar-benar diberikan secara bebas, jujur, dan objektif. Penerangan ini memperhatikan keterangan yang diberikan saksi harus benar-benar diberikan secara bebas, jujur, dan objektif. ${ }^{9}$

Pentingnya kedudukan saksi telah dimulai pada saat proses awal pemeriksaan, begitu pula dalam proses selanjutnya di Kejaksaan maupun Pengadilan, keterangan saksi menjadi acuan Hakim dalam memutus bersalah atau tidaknya terdakwa. Jadi jelas bahwa saksi mempunyai kontribusi yang sangat besar dalam upaya penegakan hukum di Indonesia.Selain itu saksi juga mempunyai hak yan diatur dalam KUHAP, yakni :

1. Hak untuk diperiksa tanpa hadirrnya terdakwa pada saat saksi

2. diperiksa (Pasal 173 KUHAP);

3. Hak untuk mendapatkan penterjemah atas saksi yang tidak paham bahasa indonesia (Pasal 177 ayat 1 KUHAP);

${ }^{8}$ Wirjono Prodjodikoro, 2017, Hukum Acara Pidana di Indonesia, Sumur, Bandung, hal. 118.

${ }^{9}$ H. R. Abdussalam, 2018, Prospek Hukum Pidana Indonesia Dalam Mewujudkan Rasa Keadilan Masyarakat, Jilid 2, Restu Agung, Jakarta, hal. 142. 
4. Hak saksi yang bisu atau tuli dan tidak bisa menulis untuk mendapatkan penerjemah (Pasal 178 ayat 1 KUHAP);

5. Hak untuk mendapatkan pemberitahuan sebelumnya selambat-lambatnya 3 hari sebelum menghadiri sidang (Pasal 227 ayat 1 KUHAP);

6. Hak untuk mendapatkan biaya pengganti atas kehadiran di sidang pengadilan (Pasal 229 ayat 1 KUHAP).

Keterangan seorang saksi dalam pembuktian suatu perkara pidana sangatlah menentukan keberhasilan mengungkapkan suatu tindak pidana yang terjadi. Namun seorang saksi saja tidak cukup untuk membuktikan kesalahan seseorang, pada Pasal 185 ayat (2) menyebutkan "Keterangan seorang saksi saja tidak cukup untuk membuktikan bahwa terdakwa bersalah terhadap perbuatan yang didakwakan kepadanya". ${ }^{8}$ Hal ini sesuai dengan asas unus testis ulus testis. Dalam UUPKDRT pada Pasal 55 menyebutkan bahwa Sebagai salah satu alat bukti yang sah, keterangan seorang saksikorban saja sudah cukup untuk membuktikan bahwa terdakwabersalah, apabila disertai dengan suatu alat bukti yang sah lainnya. Hal ini berarti satu orang saksi saja (saksi korban) sudah cukup untuk membuktikan bahwa terdakwa dapat dipersalahkan, namun harus didukung oleh alat bukti sah yang lain yakni misalnya visum et repertum untuk menjelaskan luka-luka pada tubuh korban sebagai alat bukti petunjuk.

Kemudian menurut Pasal 168 KUHAP, bahwa yang tidak dapat didengar keterangannya dan dapat mengundurkan diri sebagai saksi adalah:

a. Keluarga sedarah semenda dalam garis lurus ke atas atau kebawah sampai derajat ketiga dari terdakwa atau yang bersama-sama sebagai terdakwa;

b. Saudara dari terdakwa atau yang bersama-sama sebagai terdakwa, saudara ibu atau saudara bapak, juga mereka yang mempunyai hubungan karena perkawinan dari anak-anak saudara terdakwa sampai derajat ketiga;

${ }^{8}$ Ubwarin. E. (2015), Kebijakan Formulasi Hukum Pidana Dalam Penanggulangan Tindak Pidana Perjudian Melalui Internet (Internet Gambling), Jurnal Sasi, 21 (1), hal 46-66. 
c. Suami atau istri terdakwa meskipun sudah bercerai atau yang bersamasama sebagai terdakwa.

Saksi yang mempunyai hubungan baik sedarah, perkawinan ataupun suami atau istri terdakwa yang sudah bercerai sebagai terdakwa. Tidak dapat memberikan keterangannya. Keterangan saksi yang mempunyai hubungan sedarah maupun perkawinan sebagaimana disebutkan dalam Pasal 168 KUHAP,Jika dikaitkan dengan tindak pidana kekerasan dalam lingkup keluarga maka pada saat pembuktiannya akan mengalami banyak kesulitan khususnya untuk mendapatkan alat bukti keterangan saksi. Dalam tindak pidana kekerasan dalam keluarga yang paling mengetahui dan memahami apa yang sebenarnya terjadi adalah orang-orang dalam keluarga itu sendiri yang pada umumnya memilki hubungan darah dengan pelaku kejahatan tersebut.

UU PKDRT berangkat dengan tujuan untuk melindungi perempuan khususnya dari kekerasan dalam rumah tangga. Perempuan di anggap sebagai kelompok rentan atau subordinasi, khususnya perempuan yang banyak mengalami kasus kekerasan, khususnya dalam rumah tangga. Banyak kasus-kasus yang terjadi dan tidak dapat di selesaikan karena saksi yang menyaksikan, mendengan dan melihat peristiwa itu sangatlah terbatas, disamping masyarakat beranggapan bahwa masalah kekerasan dalam rumah tangga adalah masalah privat, padahal masalah ini sudah merupakan masalah sosial/masalah publik.

\section{Penutup}

Keterangan seorang saksi dalam perkara KDRT sangatlah minim, hal ini disebabkan karena saksi yang mendengar, melihat dan mengalami sendiri sangatlah sedikit, bahkan yang ada hanya saksi yang mengalami sendiri tindak pidana yang terjadi. Hal ini beralasan karena tindak pidana yang terjadi dalam KDRT hanya melibatkan orang-orang terdekat, dan juga terikat oleh hubungan darah bahkan perkawinan. 
Kekuatan alat bukti keterangan seorang saksi (korban) dalam memberikan keterangan di depan sidang pengadilan memiliki kekuatan sebagai alat bukti yang sah jika di dukung oleh alat bukti sah lainnya. Keterangan seorang saksi yang mempunyai hubugan darah, perkawinan mempunyai kekuatan sebagai alat bukti, karena tindak pidana yang terjadi dalam rumah tangga yang mempunyai hubungan darah, perkawinan. Selain itu Undang-undang Nomor 23 Tahun 2004 tentang Penghapusan Kekerasan Dalam Rumah Tangga merupakan hukum pidana khusus yang menyampingkan hukum pidana umum baik itu hukum pidana materiil maupun hukum pidana formil (KUHAP).

\section{Daftar Pustaka}

Adami Chazawi, (2019), Hukum Pembuktian Tindak Pidana Korupsi, Almuni, Bandung,

Andi Hamzah, (2018), Hukum Acara Pidana Indonesia, Sinar Grafika, Jakarta.

Bambang Poernomo, (2019), Pokok-pokok Hukum Acara Pidana, Liberty, Yogyakarta.

Darwan Prinst, (2019), Hukum Acara Pidana Dalam Praktik, Edisi Revisi, Djambatan, Jakarta.

H. R. Abdussalam, (2018), Prospek Hukum Pidana Indonesia Dalam Mewujudkan Rasa Keadilan Masyarakat, Jilid 2, Restu Agung, Jakarta.

Sutarto Suryono, (2019), Hukum Acara pidana jilid II. Badan Penerbit Universitas Diponegoro, Semarang.

Martiman Prodjohamidjojo, (2018), Penerapan Pembuktian Terbalik Dalam Delik Korupsi, Mandar Maju, Bandung. 
Ubwarin. E. (2015), Kebijakan Formulasi Hukum Pidana Dalam Penanggulangan Tindak Pidana Perjudian Melalui Internet (Internet Gambling), Jurnal Sasi, 21 (1), hal 46-66.

Ubwarin. E. (2015), Kebijakan Formulasi Hukum Pidana Dalam Melanggulagi Kejahatan Skimming ATM, Jurnal Sasi, 21 (2), hal 17-20

Ubwarin. E. (2014), Penegakan Hukum Yang Dilakukan Oleh Polair Polda Maluku, Jurnal Muara Ilmu Sosial, Humaniora, dan Seni, 2 (1), hal 44-51

R. Atang Ranomiharjo dalam Darwan Prinst, (2019), Hukum Acara Pidana Dalam Praktik, Edisi Revisi, Djambatan, Jakarta.

Wirjono Prodjodikoro, (2019), Hukum Acara Pidana di Indonesia, Sumur, Bandung. 